\title{
Insulin and IGF-1, but not $17 \beta$-estradiol, alter the subcellular localization of MIER1 $\alpha$ in MCF7 breast carcinoma cells
}

\author{
Shengnan Li, Gary D. Paterno and Laura L. Gillespie*
}

\begin{abstract}
Background: MIER1 $\alpha$ is a transcriptional regulator that interacts with estrogen receptor $\alpha$ and inhibits estrogenstimulated growth of breast carcinoma cells. Interestingly, analysis of MIER1 $\alpha$ subcellular localization in breast samples revealed a stepwise shift from the nucleus to the cytoplasm during progression to invasive carcinoma. Previously, we demonstrated that MIER1 $\alpha$ is nuclear in MCF7 cells yet it does not contain a nuclear localization signal. Instead MIER1 $\alpha$ is targeted to the nucleus through interaction and co-transport with HDAC 1 and 2.
\end{abstract}

Results: In this study, we demonstrate that treatment of MCF7 breast carcinoma cells with either insulin or insulinlike growth factor affects the subcellular localization of MIER1 $\alpha$. Both factors reduce the percentage of cells with nuclear MIER1 $\alpha$ from 81 and 89 to 41 and $56 \%$, respectively. Treatment with 17/-estradiol, on the other hand, had no effect and MIER1 $\alpha$ remained nuclear.

Conclusions: Our data demonstrate that insulin and IGF-1 can contribute to loss of nuclear MIER1 $\alpha$ in the MCF7 breast carcinoma cell line.

Keywords: MIER1 $\alpha$, Transcriptional regulator, Breast cancer, MCF7, Insulin, IGF-1, Estrogen, Subcellular localization

\section{Background}

MIER1 $\alpha$ is a transcriptional repressor $[1,2]$ that has been implicated as a tumour suppressor in breast cancer [3]. It interacts with $\mathrm{ER} \alpha$ and inhibits estrogen-stimulated anchorage-dependent growth of breast carcinoma cells [3]. Moreover, analysis of patient breast biopsies revealed a dramatic reduction in nuclear MIER1 $\alpha$ during progression, from $75 \%$ nuclear MIER1 $\alpha$ in normal samples to $51 \%$ nuclear in ductal carcinoma in situ to $4 \%$ nuclear in invasive ductal carcinoma [3]. Thus loss of nuclear MIER1 $\alpha$ is associated with breast cancer progression.

MIER1 represses transcription through several distinct mechanisms: it can recruit histone deacetylase (HDAC) 1 and 2 to the promoter of responsive genes [1]; it can bind Creb binding protein (CBP) and inhibit its histone acetyltransferase activity [4]; finally, it can interact directly with

\footnotetext{
*Correspondence: Igillesp@mun.ca

Terry Fox Cancer Research Laboratories, Division of BioMedical Sciences,

Faculty of Medicine, Memorial University of Newfoundland, St John's,
} NL A1B 3V6, Canada transcription factors such as Sp1 and displace them from their cognate site on target gene promoters [2]. All of these functions are dependent on localization of MIER1 $\alpha$ in the nucleus, yet it does not contain a functional NLS [5]. Instead, translocation into the nucleus is dependent on interaction and co-transport with HDAC1 and 2 [6]. In this report, we show that localization of MIER1 $\alpha$ in the nucleus of MCF7 cells is significantly reduced by treatment with insulin or IGF-1, but not by $17 \beta$-estradiol (E2). This suggests that insulin or IGF-1 could attenuate MIER1 $\alpha$ 's transcriptional repressor/chromatin modifying functions in MCF7.

\section{Methods}

The MCF7 breast carcinoma cell line was obtained from the ATCC and cultured in DMEM (GIBCO) containing $10 \%$ serum $[7.5 \%$ calf serum $(\mathrm{CS})+2.5 \%$ fetal bovine serum (FBS)] (GIBCO), in a humidified $37^{\circ} \mathrm{C}$ incubator with $5 \% \mathrm{CO}_{2}$. Insulin was purchased from Life Technologies and used at a concentration of $10 \mathrm{ug} / \mathrm{ml}$. IGF-1 
was purchased from PeproTech and used at a concentration of $10 \mathrm{ng} / \mathrm{ml}$. 17 $\beta$-estradiol was purchased from Sigma-Aldrich and used at a concentration of $10^{-8} \mathrm{M}$. For experiments using $17 \beta$-estradiol, cells were cultured in phenol red-free DMEM (GIBCO) supplemented with $10 \%$ charcoal-stripped FBS (Hyclone). Cells were treated for $4 \mathrm{~h}$ with insulin, IGF-1 or $17 \beta$-estradiol prior to fixation. Construction of the human mier $1 \alpha$ sequence (GenBank: AY124188) in the CS3 + MT vector has been described previously [1]. Transient transfection, confocal microscopy, antibodies used and Z-stack analysis were performed as described in [6, 7]. Subcellular localization was scored as 'nuclear' if the nucleus was intensely stained, with little or no cytoplasmic staining; 'cytoplasmic' if staining was primarily in the cytoplasm, with little or no staining in the nucleus; 'whole cell' if both the nucleus and cytoplasm were stained [6]. Statistical analysis was performed using a two-sided Fisher's exact test.

\section{Results and discussion}

Insulin alters nuclear localization of MIER $1 \alpha$ in MCF7 cells

We have shown previously that MIER $1 \alpha$ is targeted to the nucleus in MCF7 cells despite the lack of an intrinsic NLS [6, 7]. In those studies, cells were cultured in DMEM containing $10 \%$ CS/FBS. Several laboratories, including the ATCC, add $10 \mathrm{ug} / \mathrm{ml}$ insulin to culture media for MCF7 cells, however when we added insulin, we noticed a change in the subcellular localization pattern of MIER $1 \alpha$. To investigate this effect more thoroughly, we analysed mier1 $\alpha$-transfected MCF7 cells by confocal microscopy. In the presence of insulin, only $41 \%$ of cells had exclusively nuclear MIER1 $\alpha$ (Fig. 1Ad-f, B), compared to $81 \%$ of cells in the absence of insulin (Fig. 1Aac, B). The percentage cells with MIER1 $\alpha$ in both the nucleus and cytoplasm (whole cell staining) increased in the presence of insulin, from 18 to $42 \%$ (Fig. 1B). Likewise, the proportion of cells with exclusively cytoplasmic MIER1 $\alpha$ increased over tenfold, from 1 to $17 \%$ (Fig. 1B). These results demonstrate that in the presence of insulin, localization of MIER1 $\alpha$ in MCF7 cells is shifted from the nucleus to the cytoplasm.

Our previous research demonstrated that MIER1 $\alpha$ localizes to the nucleus through interaction and co-transport with HDAC1/2. Therefore we investigated whether insulin also affected localization of HDAC1/2. Confocal analysis demonstrated that while insulin reduces nuclear accumulation of MIER1 $\alpha$ (Fig. 2Ab, f, j), it does not affect localization of HDAC1 or 2 (Fig. 2Ac, g, k) and both were $100 \%$ nuclear (Fig. 2B).

\section{Nuclear accumulation of MIER $1 \alpha$ is affected by IGF-1, but not by E2}

IGF-1 is closely related to insulin and both can interact with the insulin and IGF receptors, albeit with differing affinities [8]. In addition, there is a wealth of evidence implicating IGF-1 in breast cancer development and progression (reviewed in [9] ) and it has been shown to increase invasiveness of MCF7 cells [10]. Since MCF7 cells express receptors for both insulin and IGFs [11], we explored the possibility that IGF-1 also affects localization of MIER1 $\alpha$. As expected, confocal analysis demonstrated that IGF-1 had a similar effect on nuclear accumulation of MIER $1 \alpha$ (Fig. 3Ab, f, j, B). IGF-1 reduced the percentage of cells with nuclear MIER1 $\alpha$ from 89 to $56 \%$ and increased the percentage with 'whole cell' staining from 10 to $40 \%$. The percent with 'cytoplasmic' MIER $1 \alpha$ was also increased from 0.3 to $4 \%$. Thus, both insulin and IGF-1 have similar effects on the subcellular localization of MIER1 $\alpha$ in MCF7.

Insulin and IGFs are potent mitogens for MCF7 cells [12], leading to the question of whether changes in nuclear accumulation of MIER $1 \alpha$ are related to the fact that the cells are proliferating. We therefore examined MIER1 $\alpha$ localization in cells treated with E2, a classic mitogen for ER + breast carcinoma cells. Unlike insulin and IGF-1, E2 had no significant effect on nuclear accumulation of MIER1 $\alpha$ (Fig. 4). In the presence of E2, $77 \%$ of cells displayed nuclear MIER1 $\alpha$ (Fig. 4Af, j, B) compared to $80 \%$ of untreated cells (Fig. 4Ab, B). Likewise there was no significant difference in the percentage of cells with 'whole cell' or 'cytoplasmic' staining (Fig. 4B). These results demonstrate that the shift in MIER $1 \alpha$ localization directed by insulin and IGF-1 is not the non-specific result of cell proliferation.

More than likely activation of one of the insulin/ IGF signalling pathways is responsible for the altered MIER1 $\alpha$ localization in MCF7. This type of effect has been observed for the FOXO family of transcription factors. For example, FOXO is driven out of the nucleus by insulin as well as other growth factors [13] and by Src signalling [14]. In C. elegans, activation of DAF-2, the nematode ortholog of the IGF-1 receptor, prevents nuclear accumulation of the DAF-16 (FOXO) transcription factor [15].

The data presented here demonstrate that for MCF7 the culture conditions, specifically the common practice of including insulin in the medium, can have important consequences for studies of nuclear proteins like MIER1 $\alpha$. 


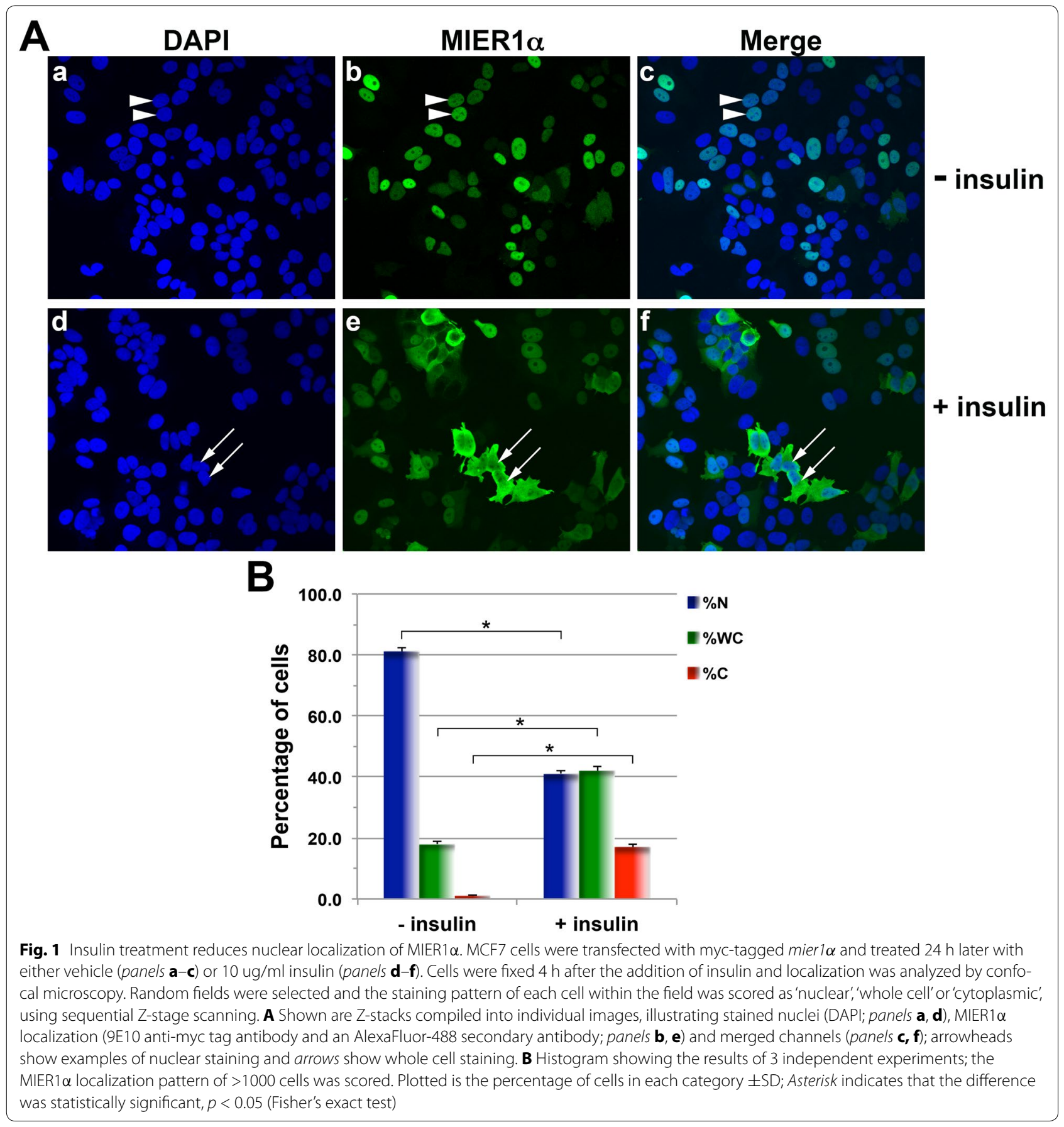




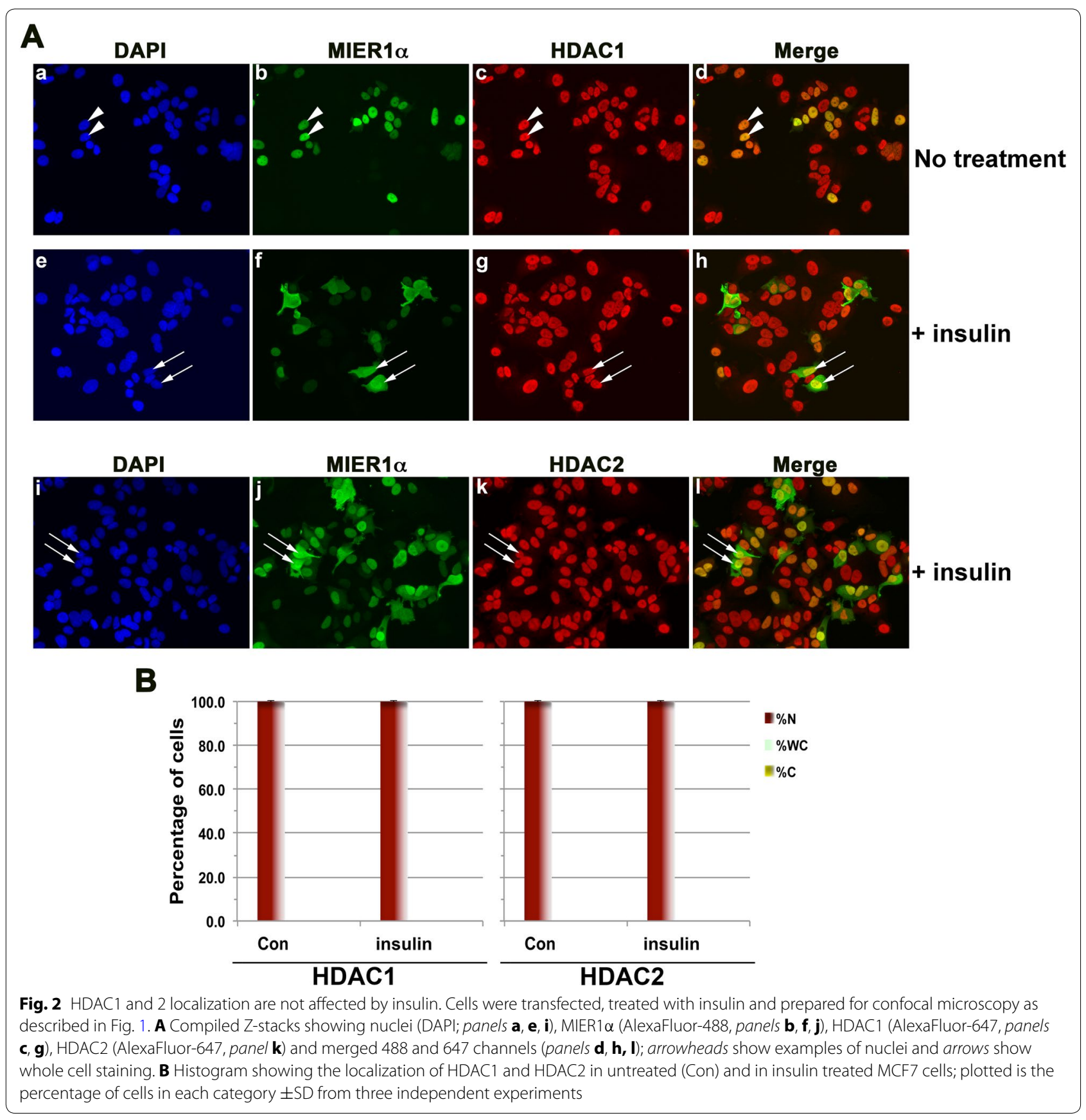




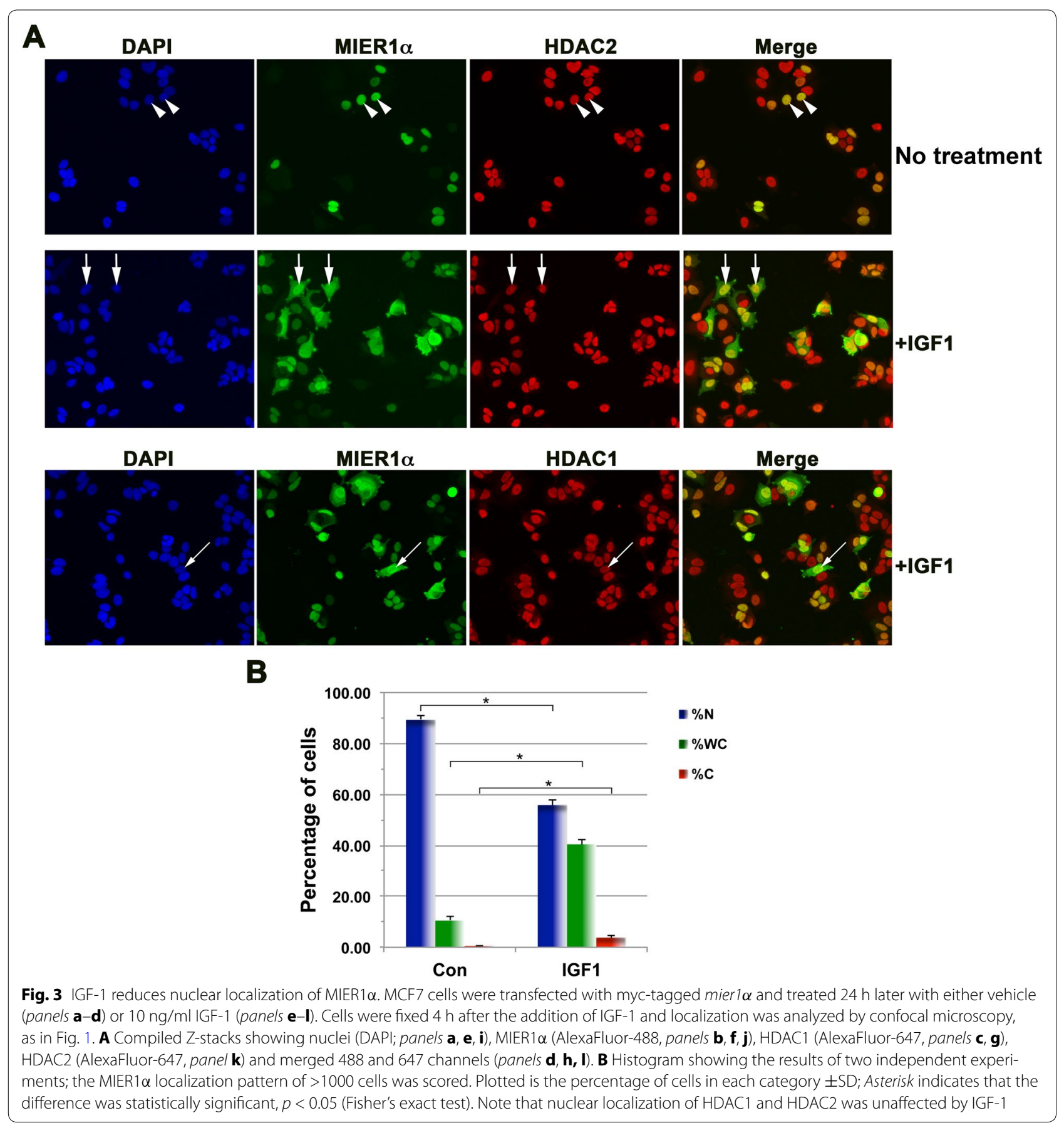




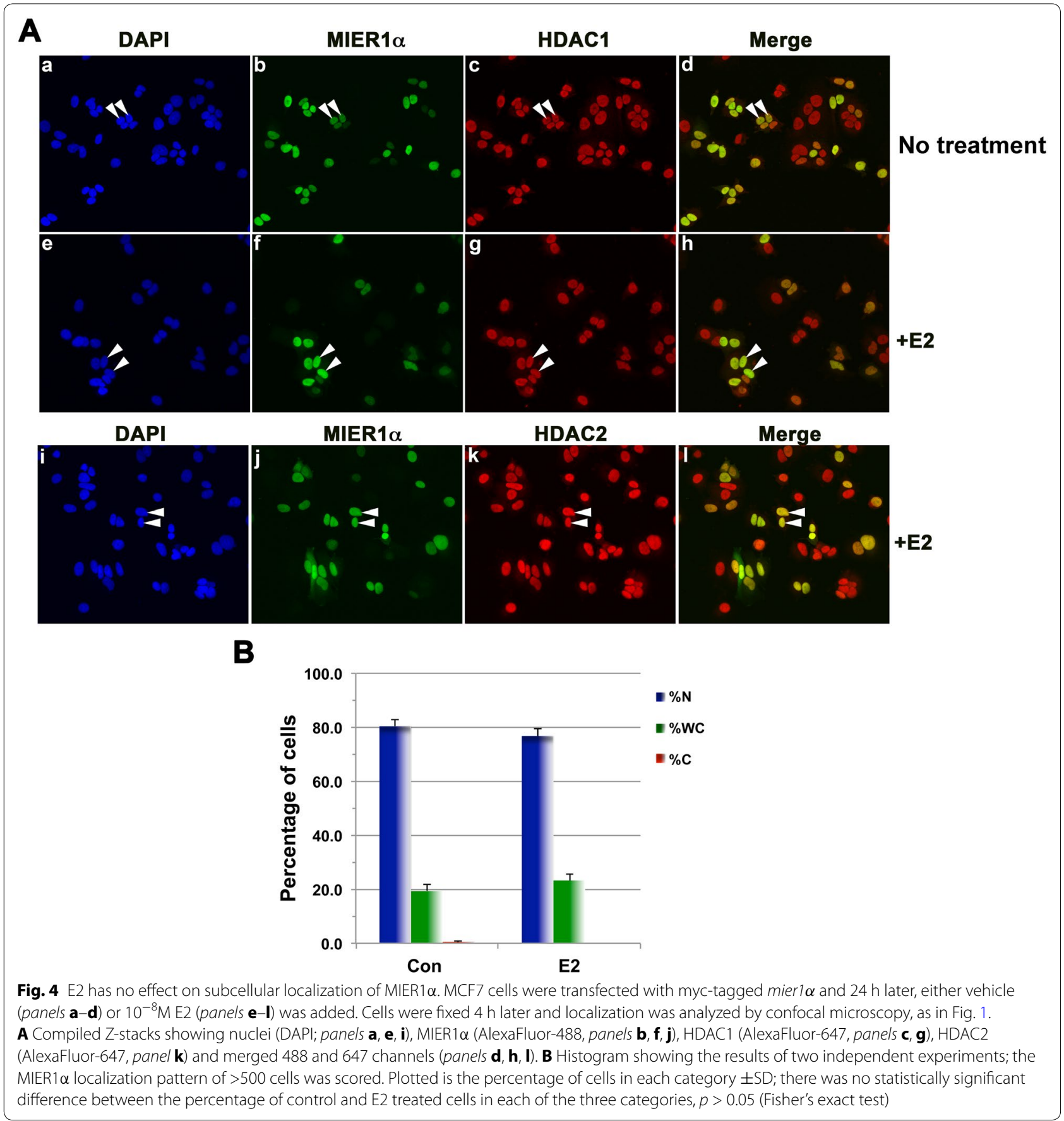

\section{Abbreviations}

CBP: creb binding protein; CS: calf serum; E2: 17- $\beta$ estradiol; ER $\alpha$ : estrogen receptor alpha; FBS: fetal bovine serum; HDAC: histone deacetylase; IGF-1: insulin-like growth factor 1; NLS: nuclear localization signal.

\section{Authors' contributions}

SL performed the experiments. LLG analysed the data, prepared the Figures and wrote the manuscript. LLG and GDP participated in the design of the experiments and interpretation of the data. All authors were involved in the revisions. All authors read and approved the final manuscript.

\section{Acknowledgements}

This work was supported by a grant from the Canadian Institutes of Health Research and the Canadian Breast Cancer Foundation-Atlantic Chapter to LLG and GDP.

\section{Compliance with ethical guidelines}

\section{Competing interests}

The authors declare that they have no competing interests. 
Received: 28 November 2014 Accepted: 12 August 2015

Published online: 18 August 2015

\section{References}

1. Ding Z, Gillespie LL, Paterno GD. Human MI-ER1 alpha and beta function as transcriptional repressors by recruitment of histone deacetylase 1 to their conserved ELM2 domain. Mol Cell Biol. 2003;23:250-8.

2. Ding Z, Gillespie LL, Mercer FC, Paterno GD. The SANT domain of human MI-ER1 interacts with Sp1 to interfere with GC box recognition and repress transcription from its own promoter. J Biol Chem. 2004;279:28009-16.

3. McCarthy PL, Mercer FC, Savicky MW, Carter BA, Paterno GD, Gillespie LL. Changes in subcellular localisation of MI-ER1 alpha, a novel oestrogen receptor-alpha interacting protein, is associated with breast cancer progression. Br J Cancer. 2008;. doi:10.1038/sj.bjc.6604518.

4. Blackmore TM, Mercer CF, Paterno GD, Gillespie LL. The transcriptional cofactor MIER1-beta negatively regulates histone acetyltransferase activity of the CREB-binding protein. BMC Res Notes. 2008; doi:10.1186/1756-0500-1-68.

5. Post JN, Gillespie LL, Paterno GD. Nuclear localization signals in the Xenopus FGF embryonic early response 1 protein. FEBS Lett. 2001;502(1-2):41-5.

6. Li S, Paterno GD, Gillespie LL. Nuclear localization of the transcriptional regulator MIER1alpha requires interaction with $\mathrm{HDAC1/2}$ in breast cancer cells. PLoS One. 2013; doi:10.1371/journal.pone.0084046.

7. Clements JA, Mercer FC, Paterno GD, Gillespie LL. Differential splicing alters subcellular localization of the alpha but not beta isoform of the
MIER1 transcriptional regulator in breast cancer cells. PLoS One. 2012; doi:10.1371/journal.pone.0032499.

8. Werner $\mathrm{H}$, Weinstein D, Bentov I. Similarities and differences between insulin and IGF-I: structures, receptors, and signalling pathways. Arch Physiol Biochem. 2008; doi:10.1080/13813450801900694.

9. Christopoulos PF, Msaouel P, Koutsilieris M. The role of the insulin-like growth factor-1 system in breast cancer. Mol Cancer. 2015;. doi:10.1186/ s12943-015-0291-7.

10. Walsh LA, Damjanovski S. IGF-1 increases invasive potential of MCF 7 breast cancer cells and induces activation of latent TGF-beta1 resulting in epithelial to mesenchymal transition. Cell Commun Signal CCS. 2011; doi:10.1186/1478-811X-9-10.

11. Cullen KJ, Yee D, Sly WS, Perdue J, Hampton B, Lippman ME, et al. Insulinlike growth factor receptor expression and function in human breast cancer. Cancer Res. 1990;50(1):48-53.

12. Bentel JM, Lebwohl DE, Cullen KJ, Rubin MS, Rosen N, Mendelsohn J, et al. Insulin-like growth factors modulate the growth inhibitory effects of retinoic acid on MCF-7 breast cancer cells. J Cell Physiol. 1995; doi:10.1002/ jcp.1041650124.

13. Greer EL, Brunet A. FOXO transcription factors at the interface between longevity and tumor suppression. Oncogene. 2005;. doi:10.1038/ sj.onc.1209086.

14. Bulow MH, Bulow TR, Hoch M, Pankratz MJ, Junger MA. Src tyrosine kinase signaling antagonizes nuclear localization of FOXO and inhibits its transcription factor activity. Sci Rep. 2014; doi:10.1038/srep04048.

15. Lin K, Hsin H, Libina N, Kenyon C. Regulation of the Caenorhabditis elegans longevity protein DAF-16 by insulin/IGF-1 and germline signaling. Nat Genet. 2001;. doi:10.1038/88850

\section{Submit your next manuscript to BioMed Central and take full advantage of:}

- Convenient online submission

- Thorough peer review

- No space constraints or color figure charges

- Immediate publication on acceptance

- Inclusion in PubMed, CAS, Scopus and Google Scholar

- Research which is freely available for redistribution

Submit your manuscript at

www.biomedcentral.com/submit

C BioMed Central 